\title{
The effect of recycled plant residues on the microbial activity of typical sandy soil of the Nyírség region
}

\author{
Ibolya DEMETER $^{1}$ - Marianna MAKÁDI ${ }^{1}$ - Bence VÉGSÖ ${ }^{1}$ - Tibor József ARANYOS ${ }^{1}$ - \\ Katalin POSTA ${ }^{2}$ \\ 1: Research Institute of Nyíregyháza, Institutes for Agricultural Research and Educational Farm, University \\ of Debrecen, 4400 Nyíregyháza, Hungary, Westsik Vilmos út 4-6.; E-mail: ibolyad85@gmail.com, \\ makadim@gmail.com, vegso.bence@gmail.com, aranyostibi@gmail.com \\ 2: Institute of Genetics, Microbiology and Biotechnology, Szent István University, 2100 Gödöllő, Hungary, Páter \\ Károly út 1.; E-mail: Posta.Katalin@mkk.szie.hu
}

Keywords: sandy soil, ecological management, conventional management, elevation position, plant residues

\section{Introduction}

The soil fertility and microbial activity of the typical sandy soils are relatively low in the Nyírség region, because these soils have acidic $\mathrm{pH}$ and low organic carbon content. The organic carbon content can be increased by recycling of plant residues, so resulting in favourable conditions for the soil microbes (Prasad et al., 2016). Furthermore, the microbial activity and biodegradation are more intensive in ecological than in conventional management system (Ge et al., 2013), and changes of soil moisture and available organic substrates could influence the microbial activity (Martin-Lammerding et al., 2015). The objective of the present study was to investigate the effect of recycled plant residues on the microbial activity in ecological farming system compared with conventional management on a light textured soil in Hungary.

\section{Materials and methods}

The investigated areas located near to Nyíregyháza, Hungary. The main soil type in this region is acidic sandy soil (Arenosol). In the ecological field buckwheat was grown, which was harvested in early October and after harvesting the plant residues were recycled to the soil. In conventional site rye with hairy vetch was harvested in early July. Soil samples were collected from the upper (EU, CU) and lower part (EL, CL) of the slopes in both sites, from the $0-30 \mathrm{~cm}$ and $30-60 \mathrm{~cm}$ soil layers immediately before the harvest, and four and six weeks after the harvesting 2018. Samples were stored at $-20{ }^{\circ} \mathrm{C}$ until the analysis. Plant samples were collected at the time of first soil sampling, from $5 * 1 \mathrm{~m}^{2}$ in the upper and the lower part of the slope of a sandy hill. Invertase activity was investigated photometrically (Mikanová et al., 2001). Soil respiration was measured in situ by an LCiSD infrared gas analyser (ADC Ltd). Soil moisture content was determined by gravimetric method. Statistical analyses were carried out with IBM SPSS Statistics 22.0 software package (IBM Inc., USA), at a significance level of 0.05 .

\section{Results and discussion}

Generally, higher invertase activity was measured in the upper $30 \mathrm{~cm}$ soil layer, than in the lower ones (except at $4^{\text {th }}$ week in EL site). Differences were observed between the two reliefs, which were significant in the most cases in both layers. The differences between the two sites changed by the sampling layer. While in case of the 0-30 cm layer higher invertase activity was measured in ecological site in $0^{\text {th }}$ and $4^{\text {th }}$ weeks, in the lower soil 
layer higher enzyme activity was observed in ecological site in all the three sampling time. The highest differences between the two sites were found in 30-60 cm layer of the lower part of the slope in the $6^{\text {th }}$ week, and on this site was found the highest change (increase) in time, too. Significant higher plant biomass production was measured in the lower part of the slope in both sampling sites, which differences was about twice in the ecological field. The recycled plant residues have found positive effect on essential substrates concentrations of soil enzymes (Wick et al., 1998) which could result in higher enzyme activities in ecological site.

Soil moisture content showed differences by topography, management and soil layer. Generally, we measured significantly higher soil moisture content $(2.74-6.90 \mathrm{~m} / \mathrm{m} \%)$ in the upper $30 \mathrm{~cm}$ soil depth in all sampling time, except of the ecological site in $6^{\mathrm{m}}$ week. The soil moisture content had strong/medium strong and significant relationship with the invertase activity $\left(0.673\right.$ in $0^{\text {th }}$ week, 0.596 in $4^{\text {th }}$ week and 0.599 in $6^{\text {th }}$ week; $\left.\mathrm{P}<0.01\right)$, and with the soil respiration also $\left(0.697\right.$ in $0^{\text {th }}$ week and 0.498 in $6^{\text {th }}$ week; $\left.\mathrm{P}<0.01\right)$.

The soil respiration showed significant differences between the two reliefs. In the $0^{\text {th }}$ and $6^{\text {th }}$ weeks were measure higher values in CL than in CU and in $4^{\text {th }}$ week the opposite of this result was observed. In case of ecological site we could measure evaluable values only the $0^{\text {th }}$ week, probably because of the cold weather.

\section{Conclusions}

All measured soil microbial parameters in ecological and conventional farming systems were affected by soil depth, topography, management and weather. In general, the invertase enzyme activity and soil moisture content were higher in the ecological site. Based on our results, recycling of plant residues can decrease the negative environmental and human effects and resulted in favourable soil conditions to the microbes. These conditions resulted in higher microbial activity and increasing soil fertility of the investigated acidic

\section{= Supported BY the ÚNKP-18-3 New National Excellence Program of MBERI EROFORRASOK
MINISZTERIUMA The Ministry of Human Capacities.}

sandy soil.

\section{References}

Ge T., Chen X., Yuan H., Zhu B. Li, H., Peng P., Li K., Jones D. L., Wu J. (2013): Microbial biomass, activity, and community structure in horticultural soils under conventional and organic management strategies. Eur. J. Soil Biol. 58, 122-128. https://doi.org/10.1016/j.ejsobi.2013.07.005

Martin-Lammerding D., Navas M., Mar Albarrán M., Tenorio J. L., Walter I. (2015): Long term management systems under semiarid conditions: Influence on labile organic matter, $\beta$-glucosidase activity and microbial efficiency, App. Soil Ecol. 96, 296-305. https://doi.org/10.1016/j.apsoil.2015.08.021

Mikanová O., Kubát J., Mikhailovskaya N., Vörös I., Bíró B. (2001): Influence of heavy metal pollution on some soil-biological parameters in the alluvium of the Litavka river. Rostlinná Výroba 47, 117-122.

Prasad J.V.N.S., Srinivasa Rao Ch., Srinivas K., Naga Jyothi Ch., Venkateswarlu B., Ramachandrappa B.K., Dhanapal G.N., Ravichandra K., Mishra P.K. (2016): Effect of ten years of reduced tillage and recycling of organic matter on crop yields, soil organic carbon and its fractions in Alfisols of semi arid tropics of southern India. Soil Till. Res. 156, 131-139. https://doi.org/10.1016/j.still.2015.10.013

Wick B., Khüne R., Vlek P. (1998): Soil microbiological parameters as indicators of soil quality under improved fallow management system in South-Western Nigeria. Plant Soil. 202, 97-107. https://doi. org/10.1023/a:1004305615397 